\title{
Metal Interconnects for Solid Oxide Fuel Cell Power Systems
}

\author{
SECA Core Technology Program \\ Phase I Topical Report
}

DOE Award Number: $\quad$ DE-FC26-02NT41569

\author{
Reporting Period \\ $10 / 01 / 02-09 / 30 / 03$
}

Principal Investigator: S. Elangovan

Contributors: S. Balagopal, M. Timper, I. Bay, D. Larsen, and J. Hartvigsen

Date Report Issued: October 2003

Ceramatec, Inc.

2425 South 900 West

Salt Lake City, UT 84119-1517 


\section{DISCLAIMER}

"This report was prepared as an account of work sponsored by an agency of the United States Government. Neither the United States Government nor any agency thereof, nor any of their employees, makes any warranty, express or implied, or assumes any legal liability or responsibility for the accuracy, completeness, or usefulness of any information, apparatus, product, or process disclosed, or represents that its use would not infringe privately owned rights. Reference herein to any specific commercial product, process, or service by trade name, trademark, manufacturer, or otherwise does not necessarily constitute or imply its endorsement, recommendation, or favoring by the United States Government or any agency thereof. The views and opinions of authors expressed herein do not necessarily state or reflect those of the United States Government or any agency thereof." 


\begin{abstract}
Interconnect development is identified by the U.S. Department of Energy as a key technical area requiring focused research to meet the performance and cost goals under the Solid State Energy Conversion Alliance initiative. In the Phase I SECA Core Technology Program, Ceramatec investigated a commercial ferritic stainless steel composition for oxidation resistance properties by measuring the weight gain when exposed to air at the fuel cell operating temperature. A pre-treatment process that results in a dense, adherent scale was found to reduce the oxide scale growth rate significantly. A process for coating the surface of the alloy in order to reduce the in-plane resistance and potentially inhibit chromium oxide evaporation was also identified. The combination of treatments provided a very low resistance through the scale. The resistance measured was as low as 10 milliohm- $\mathrm{cm}^{2}$ at $750^{\circ} \mathrm{C}$ in air. The oxide scale was found to be stable in humidified air at $750^{\circ} \mathrm{C}$. The resistance value was stable over several thermal cycles. A similar treatment and coating for the fuel side of the interconnect also showed an exceptionally low resistance of one milliohm- $\mathrm{cm}^{2}$ in humidified hydrogen at $750^{\circ} \mathrm{C}$, and was stable through multiple thermal cycles. Analysis of the scale after exposure to various atmospheres showed the presence of a stable composition. When exposed to a dual (air and hydrogen) atmosphere however, the scale composition contains a mixture of phases. Based on results to-date, the alloy selection and the treatment processes appear to be well suited for SOFC interconnect application.
\end{abstract}




\section{TABLE OF CONTENTS}

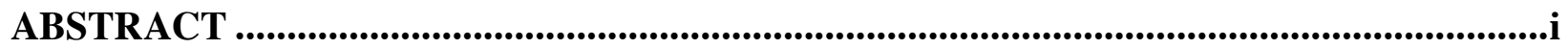

LIST OF GRAPHICAL MATERIALS ....................................................................... ii

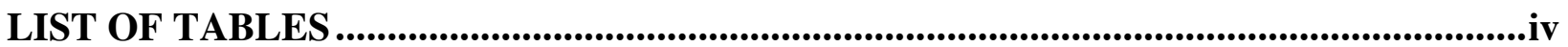

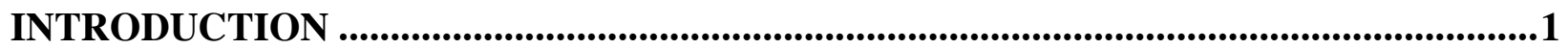

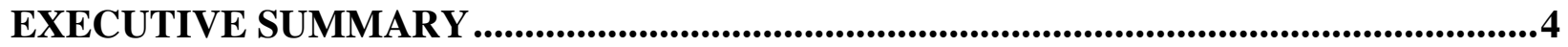

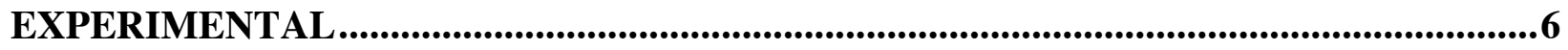

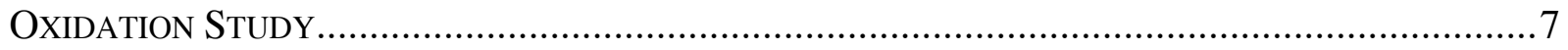

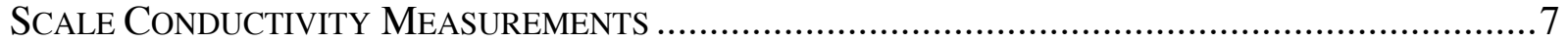

EFFECT OF HUMIDIFIED AIR AND EXPoSURE To DUAL ATMOSPHERE ......................................

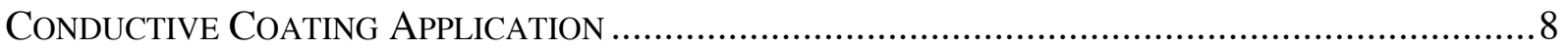

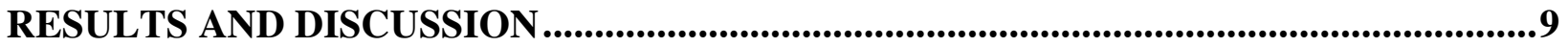

FEASIBILITY / PROOF-OF-CONCEPT DEMONSTRATION IN PhASE I ..............................................

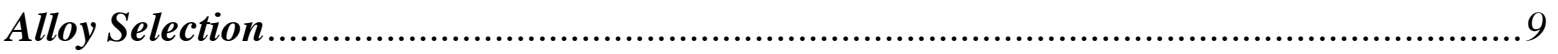

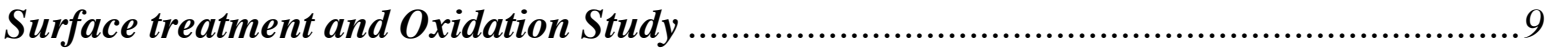

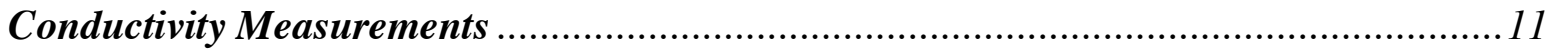

Effect of Various Exposure Conditions at $750^{\circ} \mathrm{C}$........................................................ 12

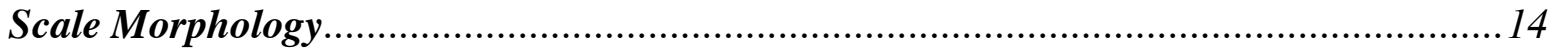

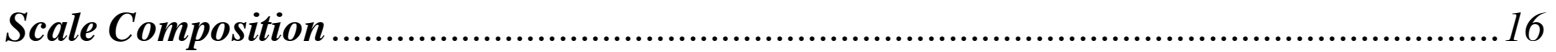

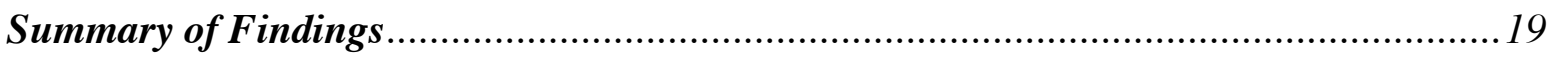

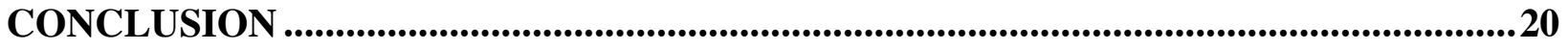

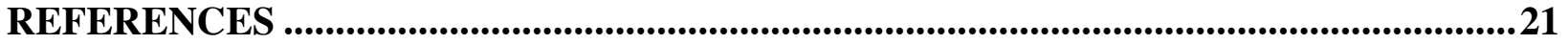




\section{LIST OF GRAPHICAL MATERIALS}

Figure 1. Interconnect Material Characterization Plan .................................................. 6

Figure 2. Coupon Conductivity Test Arrangement ......................................................... 7

Figure 3. Test Arrangement for Dual Atmosphere Exposure ...............................................8

Figure 5. Weight Gain at $850^{\circ} \mathrm{C}$ in Air as a Function of Pre-treatment Process....................... 10

Figure 6. Weight Gain at $900^{\circ} \mathrm{C}$ in Air as a Function of Pre-treatment Process........................ 10

Figure 7. Micrographs of Scale-Metal Interface after aging at $900^{\circ} \mathrm{C}$ in air for $200 \mathrm{Hours.........11}$

Figure 8. Conductivity at $900^{\circ} \mathrm{C}$ in Air as a Function of Conductive Coating Materials............ 12

Figure 9. Weight Gain when Exposed to Dry and Wet Air ................................................ 12

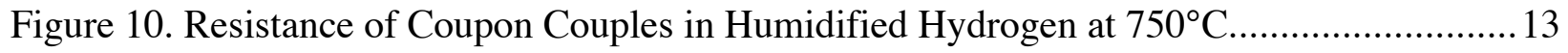

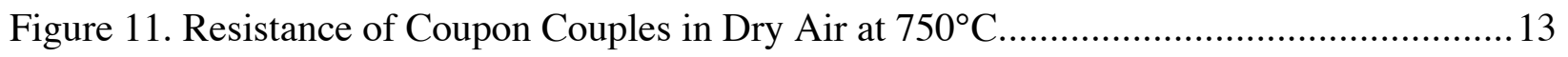

Figure 12. Micrographs of Untreated Metal...................................................................... 14

Figure 13. Micrographs of Treated Coupons (Process 50N9-4) ........................................... 14

Figure 14. Micrographs of Treated Coupons (Process 100H9-4) ........................................ 15

Figure 15. Micrographs of Dry Air Side of Dual Atmosphere Test........................................ 15

Figure 16. Micrograph for Process 50N9-4 Conductivity Tested Sample............................... 15

Figure 17. Micrograph for Process NT-0 in Wet Hydrogen ............................................ 15

Figure 18. X-Ray Diffraction Patterns of Untreated Coupons ............................................ 16

Figure 19. X-Ray Diffraction Patterns of Treated Coupons ................................................... 17 


\section{LIST OF TABLES}

Table 1. Critical Requirements of Metal Interconnects ........................................................2

Table 2. Additional Tests Recommended by SECA Participants .........................................6

Table 3. Key Milestones Proposed in Phase I and Accomplishments................................... 18 


\section{INTRODUCTION}

A variety of fuel cell technologies are currently under development, ranging from small portable units for electronic applications to large stationary power plants. The advantages of fuel cells are well known, and they include high efficiency, low emission, reliability, modularity, and vibration-free operation. High temperature fuel cells such as the Molten Carbonate Fuel Cells (MCFC) and Solid Oxide Fuel Cells (SOFC) offer additional benefits of fuel flexibility and simpler integration of system components. Recognizing the potential of fuel cell technologies, several industry-government partnerships, both in the United States and in other countries have promoted and advanced these technologies to various development, technology demonstration, and pre-commercial stages. These partnerships have resulted in commercially available $250 \mathrm{~kW}$ Phosphoric Acid Fuel Cells (PAFC) from ONSI Corporation, and a demonstration of $2 \mathrm{MW}$ Molten Carbonate Fuel Cells (MCFC) by Fuel Cell Energy. Megawatt class demonstration of PAFC system has also been conducted in Japan.

The present thrust of the Solid State Energy Conversion Alliance (SECA) program by the US Department of Energy is to advance the Solid Oxide Fuel Cell (SOFC) technology to commercial reality. The primary goal of the program is to develop a low-cost, modular SOFC stack that will form the basic building block for various power output ranges. However, major technical challenges must be overcome to achieve the goals. Critical issues for the stack are lowcost manufacturing and long-term reliability. The interconnect materials and design have remained a challenge to achieve both technical and cost goals.

The SOFC interconnect must simultaneously satisfy several functional requirements. These functions require materials with high electronic conductivity for the series connection of individual single cells, gas impermeability to separate fuel and oxidant gases, chemical stability and conductivity over a large oxygen concentration range in order to maintain integrity in both the fuel and air atmospheres. Thermal expansion match with the rest of the cell elements is desired. Although, doped $\mathrm{LaCrO}_{3}$ ceramic interconnects have been investigated, and in fact demonstrated in tubular fuel cells, their applicability in planar SOFCs was found to be limited by materials and processing costs, low electrical and thermal conductivity, and dimensional instability under an oxygen potential gradient. Metal interconnects are thus very desirable from the viewpoints of manufacturing cost in addition to other functional requirements, provided that the high conductivity can be maintained at the operating conditions. It also lends itself to ease of fabrication of gas channels and greater control over dimensions to help improve the conformity as well as uniform reactant distribution to ensure uniform current density, high fuel utilization and high fuel efficiency. The use of thin metallic sheets will also reduce overall weight in the fuel cell system. High thermal conductivity of metal interconnects will help distribute the heat generated during the operation of the cell, thereby reducing the cooling air requirement (which has cost implications via heat exchanger size), as well as eliminating thermal stress failure of ceramic components caused by sharp thermal gradients.

The critical issues that must be addressed in the development of metal interconnects are summarized below in Table 1 . 
Table 1. Critical Requirements of Metal Interconnects

\begin{tabular}{|c|c|c|}
\hline Critical Issue & Approaches tried & Hurdles for success \\
\hline $\begin{array}{l}\text { 1. Thermal expansion } \\
\text { match }\end{array}$ & Use of 95Cr-5Fe (Plansee alloy) & $\begin{array}{l}\text { Evaporation of } \mathrm{Cr} \text { is the major } \\
\text { source of degradation }\end{array}$ \\
\hline $\begin{array}{l}\text { 2. Oxidation resistance } \\
\text { in air, maintaining } \\
\text { conductive scale }\end{array}$ & $\begin{array}{l}\text { Cr containing alloys which form } \\
\text { conductive } \mathrm{Cr}_{2} \mathrm{O}_{3} \text { scale }\end{array}$ & $\begin{array}{l}\text { Cr evaporation, scale growth } \\
\text { continues to occur causing } \\
\text { high resistance contribution }\end{array}$ \\
\hline $\begin{array}{l}\text { 3. Conductive scale in } \\
\text { fuel atmosphere }\end{array}$ & Ni coating or cladding & $\begin{array}{l}\mathrm{Ni} \text { adhesion during thermal } \\
\text { cycles }\end{array}$ \\
\hline $\begin{array}{l}\text { 4. Reactivity with } \\
\text { electrode materials to } \\
\text { form insulating } \\
\text { compound }\end{array}$ & $\begin{array}{l}\text { Surface coating with } \\
\text { perovskites such as lanthanum } \\
\text { based chromite, manganite, or } \\
\text { cobaltite }\end{array}$ & $\begin{array}{l}\text { Achieving dense layers, spall } \\
\text { resistance to thermal cycles } \\
\text { are issues to be resolved }\end{array}$ \\
\hline \multirow{3}{*}{$\begin{array}{l}\text { 5. Impurity content } \\
\text { reacting with } \\
\text { electrodes or forming } \\
\text { insulating phases }\end{array}$} & Custom alloys & Cost of custom alloys \\
\hline & $\begin{array}{l}\text { Selection of low impurity } \\
\text { commercial alloys }\end{array}$ & $\begin{array}{l}\text { Commercial alloys must still } \\
\text { need to meet other } \\
\text { requirements }\end{array}$ \\
\hline & Coating of surfaces & Must also address issue $3 \& 4$ \\
\hline \multirow{2}{*}{$\begin{array}{l}\text { 6. Compatibility with } \\
\text { anode and cathode } \\
\text { environments }\end{array}$} & $\begin{array}{l}\text { Monolithic alloy with surface } \\
\text { treatments }\end{array}$ & \multirow[t]{2}{*}{$\begin{array}{l}\text { Engineering demonstration is } \\
\text { needed to prove technology }\end{array}$} \\
\hline & $\begin{array}{l}\text { Layered structure engineered } \\
\text { for appropriate atmospheres }\end{array}$ & \\
\hline \multirow[t]{2}{*}{ 7. Uniformity in contact } & $\begin{array}{l}\text { Machining or lapping to achieve } \\
\text { flatness of } 10 \text { microns }\end{array}$ & May be cost prohibitive \\
\hline & Use of corrugated layers & $\begin{array}{l}\text { Selection of appropriate layer } \\
\text { materials }\end{array}$ \\
\hline \multirow{2}{*}{$\begin{array}{l}\text { 8. Thermal cycle } \\
\text { capability }\end{array}$} & \multirow[t]{2}{*}{ No information available } & Scale spalling \\
\hline & & CTE mismatch \\
\hline 9. Cost & Use of commercial alloy & $\begin{array}{l}\text { Must meet all other } \\
\text { requirements }\end{array}$ \\
\hline
\end{tabular}

The critical requirements of metal interconnects can be summarized as follows: 1) thermal expansion match with other cell components, 2) oxidation resistance in air and fuel at the operating temperature, 3 ) conductive interface (scale) in air and fuel atmospheres, 4) prevention of reactivity with electrode materials to form insulating compounds, 5) volatilization and condensation of major or minor constituents that poison electrode activity, 6) compatibility with anode and cathode environments, 7) uniformity in contact with the cells, 8) thermal cycle capability, and 9) cost. Additionally, depending on the stack design, the interconnects could also play a role in stack heat removal, partial hydrocarbon reformation, and mechanical support for the cells. When operating on hydrocarbon fuels, it is also vital that the interconnect material is resistant to carburization. Sulfur tolerance is also desired in case of system simplification with low sulfur containing fuels or when sulfur slip occurs from inadequate sulfur clean up. These factors are common to all designs and concepts contemplated by the various SECA industrial teams. 
The use of metal interconnects, while well studied, has posed considerable challenges. An extensive report on this topic along with a collection of commercial alloy properties is in the literature. ${ }^{1,2}$ Typical austenitic or ferritic materials undergo rapid corrosion at the temperatures of SOFC operation, leading to large and unacceptable increases in resistance. Thermal cycling is also difficult, since the metals have higher thermal expansion coefficients compared to other cell materials such as zirconia. In work reported by Siemens, Germany that used a powder metallurgical $\mathrm{Cr}-5 \mathrm{wt} \% \mathrm{Fe}-1 \mathrm{wt} \% \mathrm{Y}$ alloy, corrosion of the alloy and in particular, the evaporation of $\mathrm{Cr}$ species was found to result in degradation in SOFC performance ${ }^{3}$ even though the alloy scale resistance was low and the interconnect had exact thermal expansion match to zirconia. To mitigate this problem, the metal interconnect was coated with a perovskite such as lanthanum manganite or chromite, to impart oxide scale conductivity and suppress the Cr evaporation. Scale modification using cerium ${ }^{4}$ or other reactive element ${ }^{5}$ is known to reduce the scale growth while imparting higher conductivity to the scale. As the equilibrium partial pressure of chrome-chrome oxide is extremely low, below the partial pressure of typical fuel gas, the oxide is formed even in humidified hydrogen atmosphere. It has been suggested, ${ }^{6}$ that at lower temperatures $\left(800^{\circ} \mathrm{C}\right)$ the electronic conductivity in $\mathrm{Cr}_{2} \mathrm{O}_{3}$ is extrinisic (dependent on dopant concentration), which explains the low conductivity observed in fuel atmospheres. ${ }^{7}$ Thus, it is equally important to explore technical solutions to achieve low resistance in fuel atmosphere, as it is to reduce the scale resistance in air. In prior work at Ceramatec ferritic stainless steel alloys were investigated. Typically, these alloys have around $20 \% \mathrm{Fe}$ and form a $\mathrm{Cr}_{2} \mathrm{O}_{3}$ scale. These alloys were found to offer good oxidation resistance as well as a thermal expansion coefficient reasonably close to that of zirconia from room temperature to $700^{\circ} \mathrm{C}$, permitting their use in SOFC applications. However, additional issues related to long-term stability in air, performance in wet air and wet fuel, and thermal cycles needed to be addressed. In Phase I, the tasks were aimed at addressing the issue of oxide scale growth both in air and fuel atmospheres and the associated increase in electrical resistance by a surface treatment process.

Successful completion of the work will eventually lead to stacks with stable operating characteristics at the target operating temperatures of $750-850^{\circ} \mathrm{C}$ (nominal) and with the desired low resistance arising from the stable and conductive materials developed. The commercial alloy that is under consideration for the interconnect can be purchased at $\$ 2$ per pound in the final use thickness. Featuring the thin sheets, corrugating and welding or brazing to form the final structure is fairly routine and inexpensive in the metal forming industry. The conventional lanthanum chromite ceramic or high chrome alloy interconnects are projected to be $\$ 30$ to $\$ 50$ per pound in powder form even in large commercial scale and thus form a significant cost element of the SOFC stack. Additionally, both ceramic and conventional high chrome interconnects require expensive fabrication routes. The interconnect alloy selected in Phase I is low cost, is compatible with both SOFC and other high temperature electrochemical ceramic electrochemical devices. In fact, at the current developmental stage, the materials and fabrication costs Ceramatec incurs for the metal interconnect is $\$ 20$ per $10 \times 10 \mathrm{~cm}$. At the commercial scale the cost is expected to be about $\$ 2$ per part. At a modest stack power density of $500 \mathrm{~mW} / \mathrm{cm}^{2}$, the final assembly-ready interconnect cost would be less than $\$ 50 / \mathrm{kW}$. Additional cost reduction is expected with stacks of larger footprint and higher power density. Thus the metal interconnect process development will enable fabrication of SOFCs possessing cost competitive performance and endurance characteristics required for commercialization. 


\section{EXECUTIVE SUMMARY}

The U.S. Department Energy's Solid State Energy Conversion Alliance (SECA) initiative has identified the development metal interconnects for the solid oxide fuel cells (SOFC) to be a priority core technology need for the SECA industrial teams, second only to the seal materials development. The interconnect materials make electrical series connection from one cell to the next to form a stack. The importance of metallic interconnects arises from their potential for lowering both the materials and manufacturing costs of a key stack component. Successful development and demonstration of metal interconnects will enable achieving the SECA cost target for the SOFC stack.

The technical challenges in the use of metal interconnect are related primarily to high temperature corrosion in air at the stack operating temperature. Typical corrosion resistant alloys form an oxide phase on their surface at the service temperature, which prevents the alloy from additional corrosion. However, such oxide scales are electrically insulating and thus unsuitable for use as interconnects. Alloys that form a conductive scale are chromium based alloys. At the expected stack operating temperature the chromia scale growth is expected to continue and add to the interfacial electrical resistance, as well as evaporate and condense on the cathode to deactivate the cathode. Both mechanisms lead to stack performance degradation. In Phase I feasibility study, Ceramatec investigated a low cost commercial ferritic stainless steel alloy for high temperature corrosion and electrical properties and methods of improving such properties to facilitate its use as SOFC interconnects.

The approach evaluated in Phase I consisted of two surface treatment techniques. The first one involved pre-treatment of the alloy surface in order to a) reduce the oxide scale growth rate, and b) improve the electronic conductivity of the scale at temperature. A pre-treatment technique was identified that accomplished both objectives. Additionally, the resulting surface oxide scale was dense, well-adhered, and found to contain a stable chromium containing oxide phase that is known to show exceptional stability in SOFC environment as well to possess significantly lower chromium activity. In fact, the oxide scale formed was stable in both dry air and humidified air after 500 hours of exposure at $750^{\circ} \mathrm{C}$. The stability of typical chrome oxide scale is known to be unstable in presence of moisture and tended to exhibit poor adhesion. The second treatment consisted of applying a conductive coating on top of the pre-treated surface. The purpose of the coating was two fold: a) to reduce the in-plane resistance of the interconnectcathode interface, and b) to prevent the evaporation of chrome oxide from the metal oxide surface. In order to meet both the objectives, the conductive coating must be dense and well adhered to the oxide scale. A coating technique was down-selected to give the desired physical properties. The resistance of metal coupons with the two surface treatments, pre-oxidation and application of conductive coating, was measured. The combination of processes that showed the exceptional stability in terms of slow oxide scale growth, and low weight gain in oxidation experiments, also showed the lowest resistance. The measured resistance through a coupon couple, consisting of two oxide scale layers, was 10 milliohm- $\mathrm{cm}^{2}$, nearly an order of magnitude lower than target. 
A similar pre-treatment on the fuel side was also found to be beneficial in lowering the scale resistance. The coating appropriate for the fuel atmosphere and the application technique were also identified. Resistance values of one milliohm- $\mathrm{cm}^{2}$ were measured in humidified hydrogen.

Thermal cycle capability is an important requirement for practical fuel cell applications. The conductivity coupons that showed low resistances were thermal cycled three times. Both in air and in fuel, negligible increase in resistance was observed.

More extensive investigations are planned to measure the stability of conductivity when the interconnect alloy is exposed to air and fuel conditions on opposite sides to simulate the stack operating environment. Based on results to-date, the alloy selection and the treatment processes appear to be well suited for application as SOFC interconnects. 


\section{EXPERIMENTAL}

The work plan for evaluating the ferritic stainless steel involved three types of characterization, and correlation of data. The evaluation process is outlined in Figure 1. The metal coupons are to be monitored for oxidation properties by measuring weight gain and electrical resistance as a function of time at temperature.

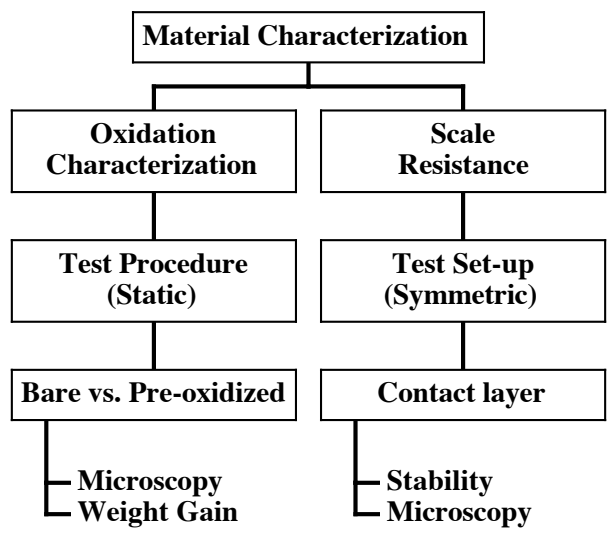

Figure 1. Interconnect Material Characterization Plan

Discussion with various SECA core technology participants and industrial teams identified several additional test conditions that needed to be included in Phase I evaluation. A summary of the discussion is given in Table 2. The test plan was modified to include the suggestions from the team.

Table 2. Additional Tests Recommended by SECA Participants

\begin{tabular}{|c|c|c|c|}
\hline Test Conditions & Recommendation & By & Modified Plan \\
\hline \multirow{2}{*}{ Temperature } & $750,800,850 \mathrm{C}$ & Delphi & \multirow{2}{*}{$\begin{array}{l}750 \mathrm{C} \text { (more } \\
\text { representative target } \\
\text { SOFC temperature) }\end{array}$} \\
\hline & Higher (900 C) & Pitt & \\
\hline \multirow{3}{*}{ Test Atmosphere } & Ambient and wet air & \multirow{3}{*}{$\begin{array}{l}\text { Pitt, PNNL, } \\
\text { LBNL, Delphi }\end{array}$} & \multirow{3}{*}{$\begin{array}{l}\text { Individual and various } \\
\text { combinations }\end{array}$} \\
\hline & Wet hydrogen & & \\
\hline & Dual atmosphere & & \\
\hline \multirow{2}{*}{ Duration (hrs) } & 1000 's & Delphi & \multirow{2}{*}{ Plan extended to $500 \mathrm{hrs}$} \\
\hline & Longer than 200 & PNNL and Pitt & \\
\hline Thermal Cycle & Include in evaluation & $\begin{array}{l}\text { Delphi, LBNL } \\
\text { and PNNL }\end{array}$ & $\begin{array}{l}\text { On selected coupons } \\
\text { after several } 100 \text { hours } \\
\text { of isothermal tests. }\end{array}$ \\
\hline
\end{tabular}

Pitt $=$ University of Pittsburgh, PNNL $=$ Pacific Northwest National Laboratory, LBNL $=$ Lawrence Berkeley National Laboratory 


\section{Oxidation Study}

Coupons of the alloy, $1 \mathrm{~cm} \times 1 \mathrm{~cm}$, were cut, degreased, and etched with phosphoric acid to clean the surface oxide layer. Various pre-treatment conditions were selected to treat the surface of the coupons for oxidation study. Initial tests were conducted at 850 and $900^{\circ} \mathrm{C}$. Both the treated and untreated coupons were annealed in a furnace. Samples were pulled at various times and weighed to monitor the weight gain. Based on the core technology peer group discussion, the annealing temperature was selected to be $750^{\circ} \mathrm{C}$ for additional study.

\section{Scale Conductivity Measurements}

The conductivity of the oxide scale was measured using a symmetric arrangement, shown in Figure 2. This arrangement was selected in order to avoid the use of Pt ink on the scale. If cracks developed with increasing scale thickness, this arrangement would prevent electromigration of $\mathrm{Pt}$ into the cracks causing artificially lower resistance. In the symmetric arrangement, two coupons were assembled with the pre-treated surfaces against each other. A highly conductive perovskite ink, typically cobaltite, was applied over the coupon surfaces to ensure good electrical contact between them.

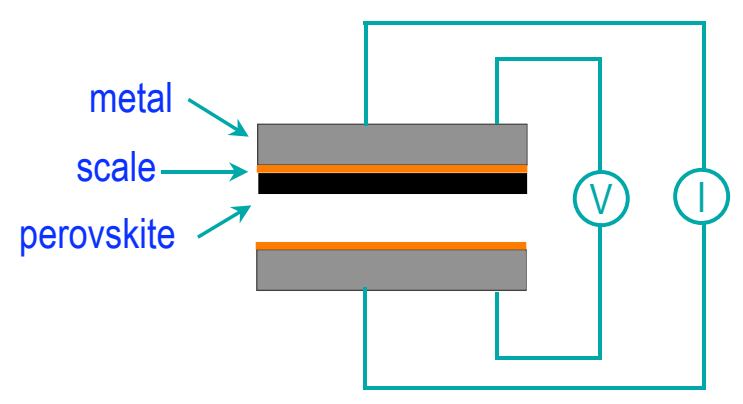

Figure 2. Coupon Conductivity Test Arrangement

\section{Effect of Humidified Air and Exposure to Dual Atmosphere}

The test plan included exposing the metal foil of the alloy to the following conditions:

a) dry ambient air,

b) humidified $\left(3 \% \mathrm{H}_{2} \mathrm{O}\right)$ air,

c) dual atmospheres

i. dry air and wet air across the foil

ii. dry air and humidified hydrogen across the sample

In order to conduct these experiments, metal foils were used. Based on promising pretreatments conditions selected from weight gain measurements, the foil surfaces were pre-treated with processes that were appropriate for the atmosphere. The foil was cemented between two zirconia tubes and assembled in a furnace. The test arrangement is shown in Figure 3. In tests using humidified hydrogen on one side of the foil, the zirconia tube itself was used as an oxygen sensor to monitor the integrity of the cement seal. The air side of the zirconia tube was used as the reference electrode for the sensor. The tests were conducted at $750^{\circ} \mathrm{C}$ for 500 hours and the samples were then analyzed using x-ray diffraction technique for phase analysis of the oxide scale and the scanning electron microscope for scale thickness, morphology, and integrity. 


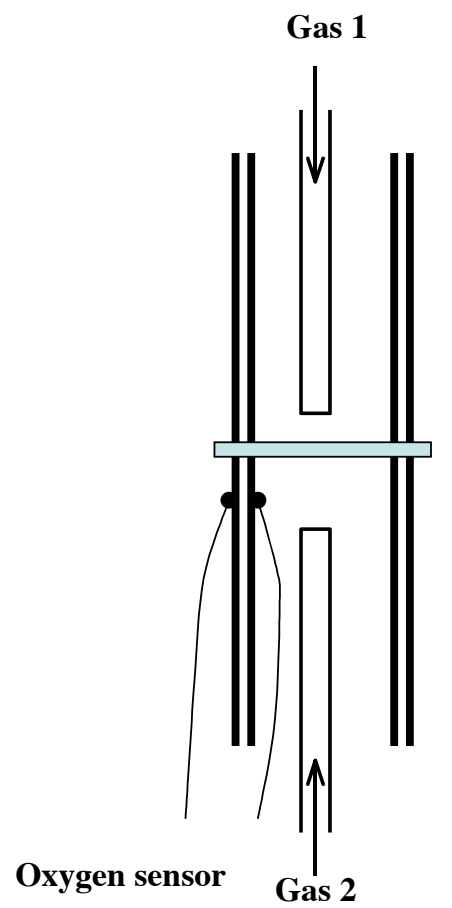

Schematic

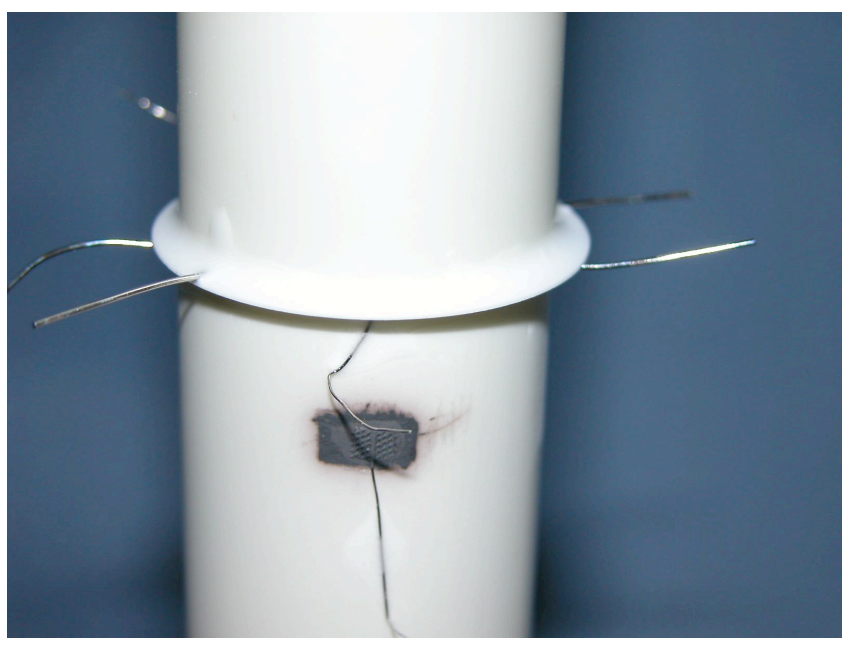

Test Hardware

Figure 3. Test Arrangement for Dual Atmosphere Exposure

\section{Conductive Coating Application}

The purpose of the conductive coating over the pre-treated surface is two-fold: on the air side of the interconnect the coating will prevent chrome evaporation and on both air and fuel sides the appropriate coating will reduce the in-plane electrical resistance. Initial coatings, perovskite on the air side and nickel on the fuel side, were applied using screen printable inks. This provided a means to evaluate the nature of the printed layer as well as to provide a means to conduct the electrical conductivity measurements in coupon tests, discussed earlier. In order to achieve a dense coating, a spray technique was evaluated. Pre-treated coupons were sprayed with the appropriate layer and used for conductivity measurements. Selected coupons were also subjected to multiple thermal cycles. 


\section{RESULTS AND DISCUSSION}

In Phase I, the primary focus of the work was to study the feasibility of using ferritic stainless steel as the interconnect. Several pre-treatment processes were evaluated to study their effect on the scale conductivity and long-term stability. In this topical report, much of the initial screening tests that did not show promising scale properties are not included. All the goals of the Phase I project however have been accomplished.

The accomplishments in Phase I are summarized below.

\section{Feasibility / Proof-of-concept Demonstration in Phase I}

The proposed activities in Phase I included: a) selection of atmosphere-appropriate surface treatment process conditions and conductive coatings for the anode and cathode sides of metal coupons, b) evaluation of interfacial resistance behavior as a function of time in air and humidified hydrogen after appropriate treatments, c) analysis of interfacial microstructure for scale thickness, morphology and chemistry, and d) data analysis to identify and recommend future work to mature the technology further for industrial team evaluation. Initial evaluations using metal coupons were conducted at 850 and $900^{\circ} \mathrm{C}$. After a detailed discussion with the DOE project officer along with several SECA participants (Pacific Northwest National Lab., Delphi, University of Pittsburgh, and Lawrence Berkeley National Lab.), additional tasks that are critical to the project were identified. Those are: evaluation of behavior at a lower temperature $\left(750^{\circ} \mathrm{C}\right)$, effect of humidified air, and simultaneous exposure to hydrogen and air on opposite sides. All the added tasks were also completed in Phase I.

\section{Alloy Selection}

A commercial stainless steel alloy was selected for evaluation. The alloy selection was based on the following general criteria set forth earlier: conductive oxide scale (chromia former), thermal expansion compatibility (for thermal cycles), impurity content (low $\mathrm{Si}$ and $\mathrm{Al}$ that form insulating phases), and low propensity for chrome vaporization ( $20 \% \mathrm{Cr}$ alloy). The selected alloy has a thermal expansion coefficient (CTE) of $11.5 \mathrm{ppm} /{ }^{\circ} \mathrm{C}$ (room temp. $-500^{\circ} \mathrm{C}$ ) and 12.6 $\mathrm{ppm} /{ }^{\circ} \mathrm{C}\left(200-700^{\circ} \mathrm{C}\right)$ compared to $11 \mathrm{ppm} /{ }^{\circ} \mathrm{C}$ for 8 mole $\%$ yttria doped zirconia (YSZ) and 13 $\mathrm{ppm} /{ }^{\circ} \mathrm{C}$ for the anode. Thus the CTE over the temperature of interest the alloy falls between the two critical components of SOFCs.

\section{Surface treatment and Oxidation Study}

The purpose of surface treatment is two fold: a) it results in a dense oxide scale of uniform thickness and b) it selectively forms either a conductive chromia based or chromium containing oxide scale. After evaluating a variety of surface treatment processes, separate process steps were found to be optimal for the anode and cathode environments. The conditions for treatment to grow the initial oxide scale was however kept identical so that a full interconnect that would face both atmospheres can be treated without the complication of process incompatibility. The treated and untreated coupons were aged at different temperatures. Initial measurements were done at 850 and $900^{\circ} \mathrm{C}$. The sample weight gain is plotted against time at temperature in Figures 6 and 7. It can be seen that the untreated bare sample gained weight at a considerably faster rate than the three pre-treatment processes, at both temperatures. 
The tested samples were analyzed using the scanning electron microscopy for scale thickness and microstructure. The scale thickness values (Figure 8) are consistent with weight gain measurements, in that the sample with the thinnest scale also showed the lowest weight gain.

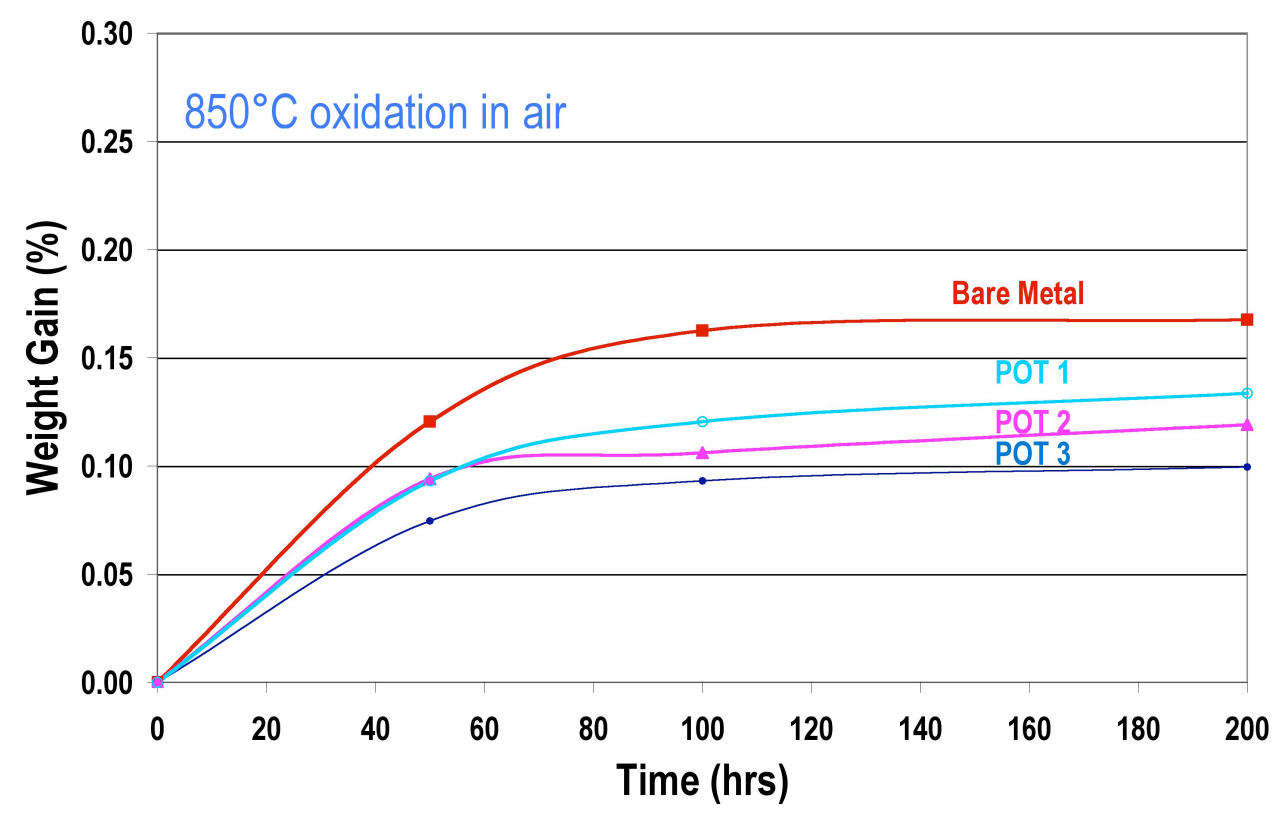

Figure 4. Weight Gain at $850^{\circ} \mathrm{C}$ in Air as a Function of Pre-treatment Process

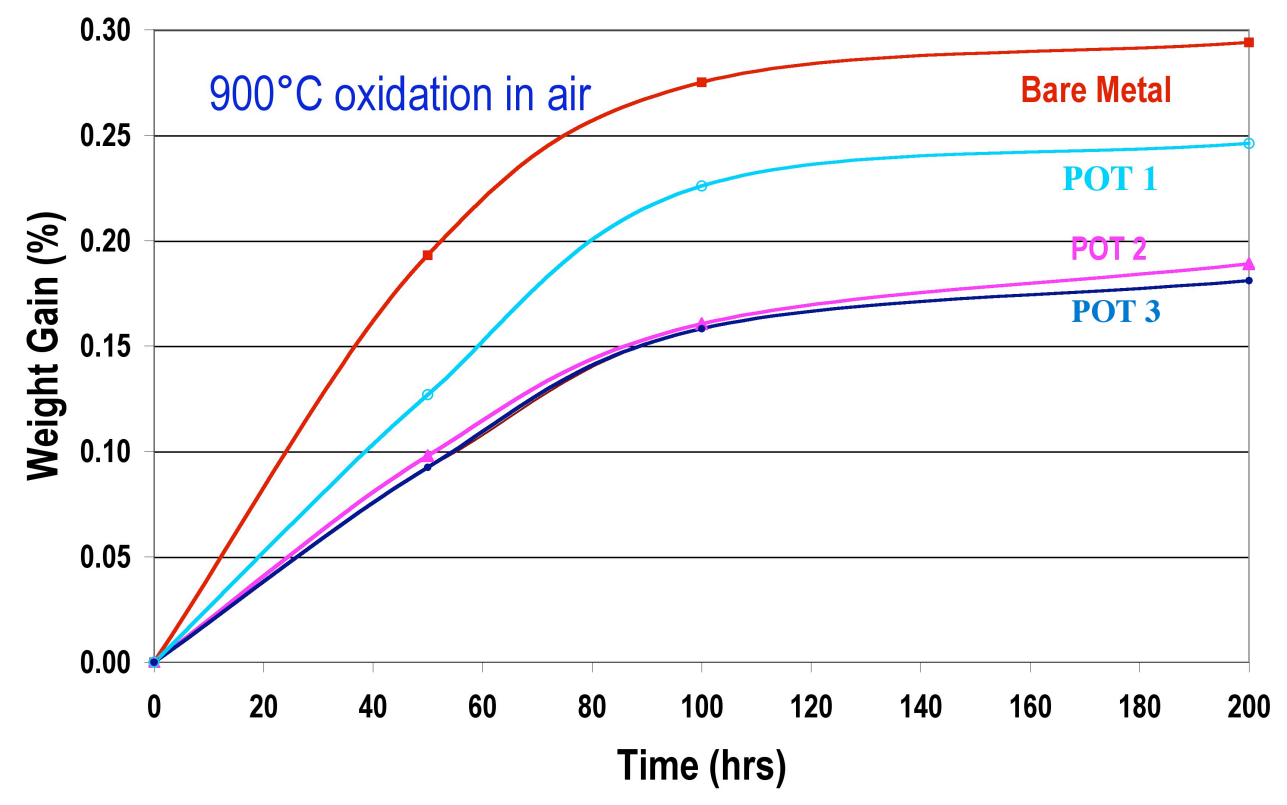

Figure 5. Weight Gain at $900^{\circ} \mathrm{C}$ in Air as a Function of Pre-treatment Process 


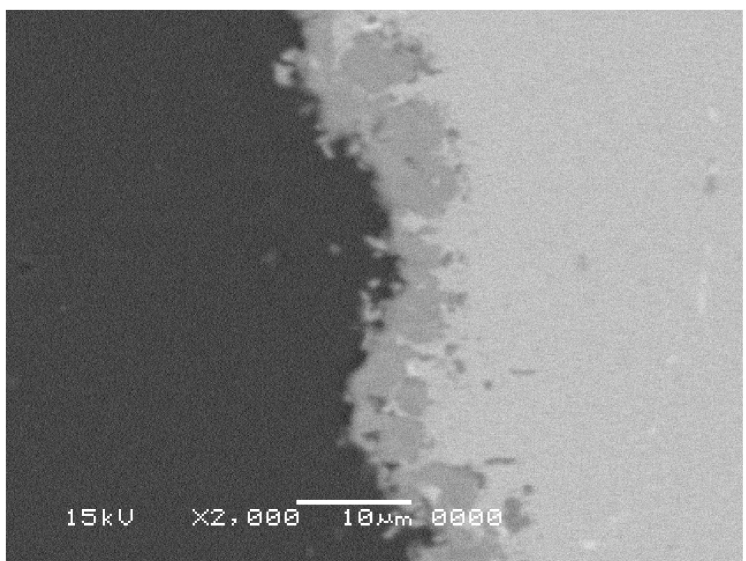

Bare Metal

Scale thickness 7 microns

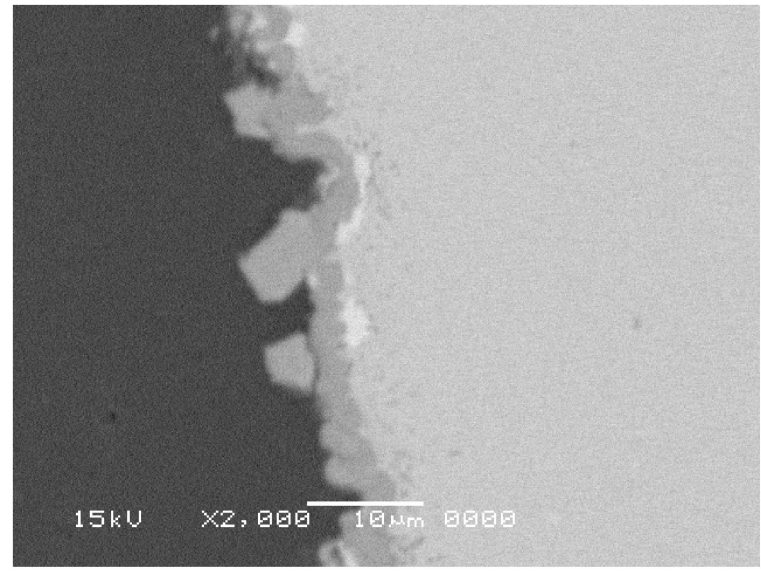

Process: 100H0-4 (POT2)

Scale thickness 5 microns

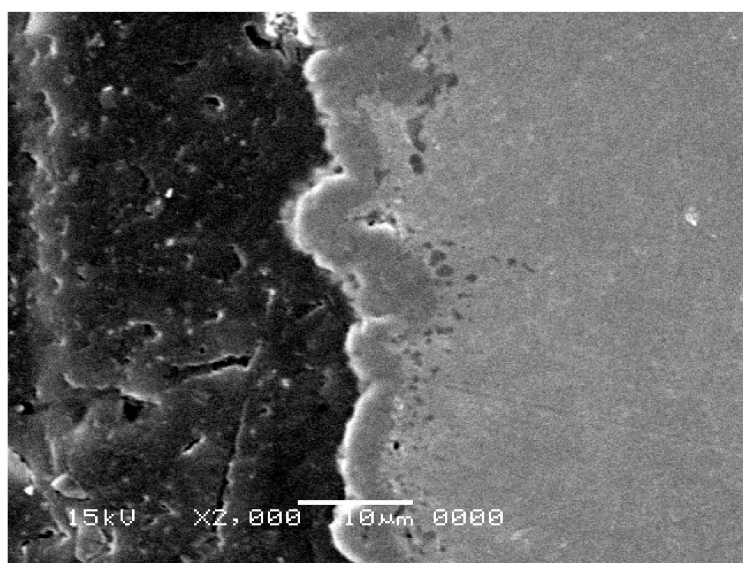

Process: 10050H9-4 (POT1)

Scale thickness 5 microns

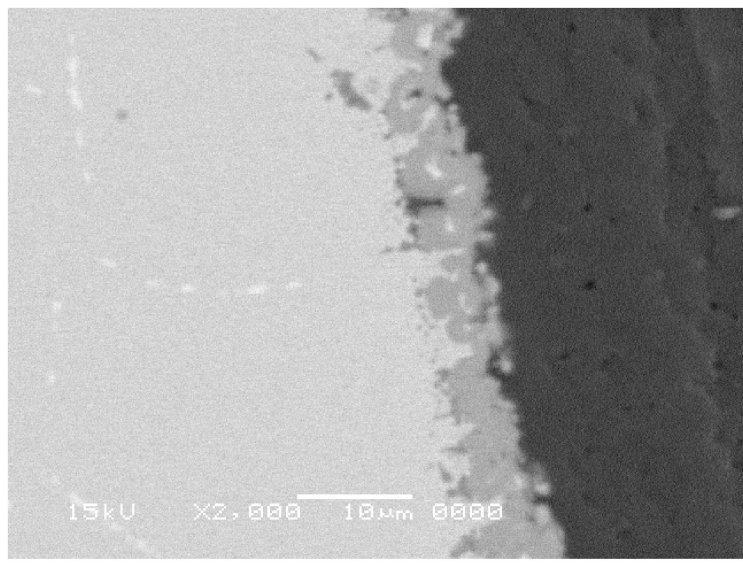

Process: 50N9-4( POT3)

Scale thickness 3 microns

Figure 6. Micrographs of Scale-Metal Interface after aging at $900^{\circ} \mathrm{C}$ in air for $200 \mathrm{Hours}$

\section{Conductivity Measurements}

In addition, an atmospheric specific conductive coating was applied to the treated sample. For the air, different perovskite materials were evaluated. The purpose of the conductive coating, if applied as dense layer, is to limit the chromia evaporation and to reduce the in-plane resistance of the interconnect. Screen printing technique was employed for the initial screening, although the printed layer was expected to be porous and not completely eliminate the potential evaporation of chromium oxide. In the screening experiments some porosity in the layer was not expected to influence the conductive measurements. The interfacial resistance of the treated/ coated alloy was measured using a symmetric couple of the following arrangement: alloy/treated interface/coating II coating/treated interface/alloy, shown in Figure 2. Thus, the measured resistance included two interfaces of interest. The lowest resistance was seen with cobaltite based conductive layer while the highest resistance was with a chromite layer. Again, the initial conductivity measurements were done at the higher temperatures. 


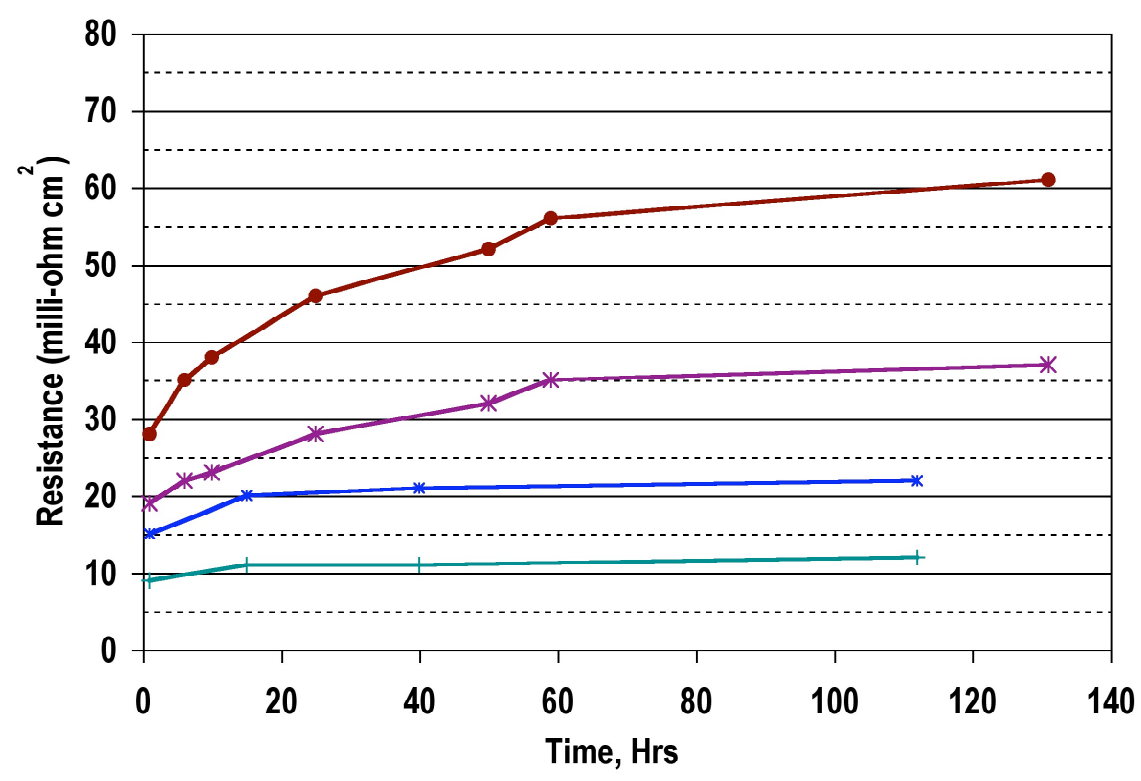

Figure 7. Conductivity at $900^{\circ} \mathrm{C}$ in Air as a Function of Conductive Coating Materials

\section{Effect of Various Exposure Conditions at $750^{\circ} \mathrm{C}$}

Based on our discussions with peer core technology program participants and some of the industrial teams, particularly Delphi, additional test conditions were included. They are: tests at $750^{\circ} \mathrm{C}$, comparison of dry and wet air, and dual atmosphere exposure. The two treatments that produced scales with promising characteristics were selected. The weight gain at the early time periods were negligible. Figure 9 shows the weight gained after 500 hours of exposure to dry or wet air $\left(\sim 3 \% \mathrm{H}_{2} \mathrm{O}\right)$. The pre-treatements caused significant reduction in the weight gain relative to untreated samples. The difference is much more dramatic in wet air exposure conditions.

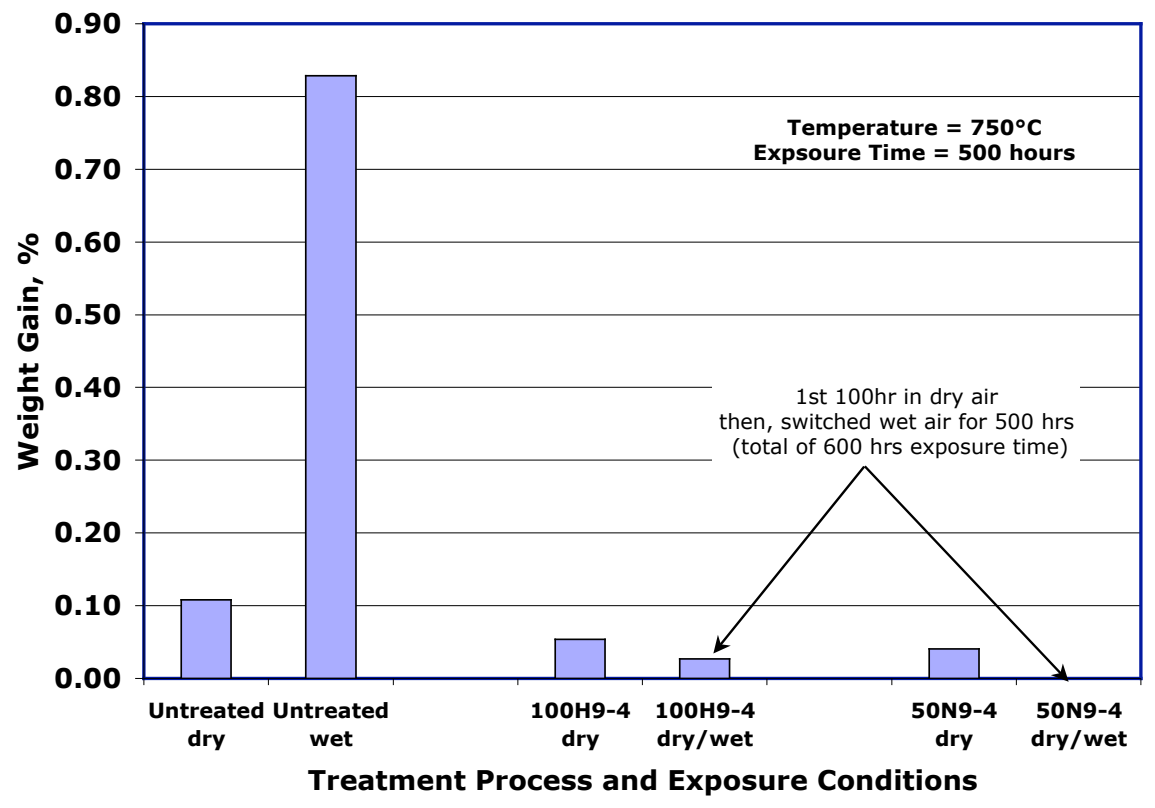

Figure 8. Weight Gain when Exposed to Dry and Wet Air 
Using the best combination of treatments and coatings appropriate for the anode and cathode atmospheres, the resistance of coupon couples was measured in air and in humidified hydrogen. The results are shown in Figures 10 and 11. In humidified hydrogen, the resistance is well below 1 milliohm- $\mathrm{cm}^{2}$ while in air it is less than 10 milliohm- $\mathrm{cm}^{2}$. Additionally, the coupon couples have been subjected to several thermal cycles and they were found to exhibit good stability. Even after numerous thermal cycles, the air side and fuel side resistance values were well below the target values. The thermal cycles were done using natural furnace cooling (power turned off) and rapid heat up at the rate of $10^{\circ} \mathrm{C}$ per minute.

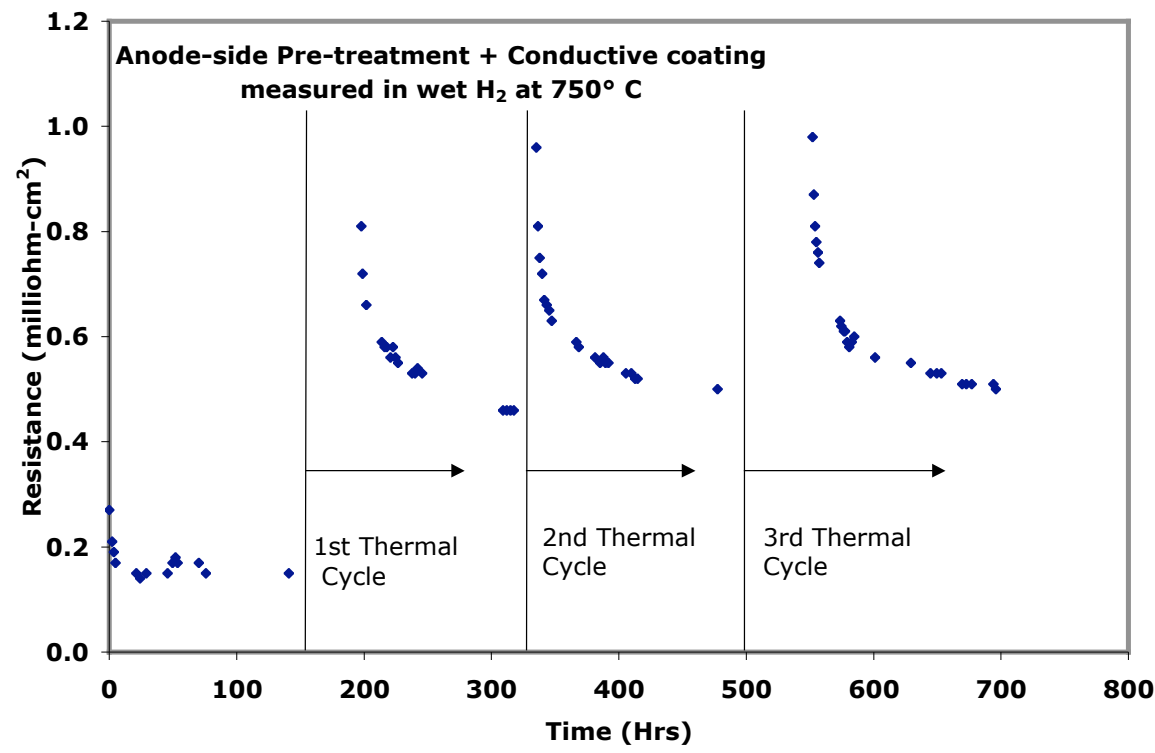

Figure 9. Resistance of Coupon Couples in Humidified Hydrogen at $750^{\circ} \mathrm{C}$

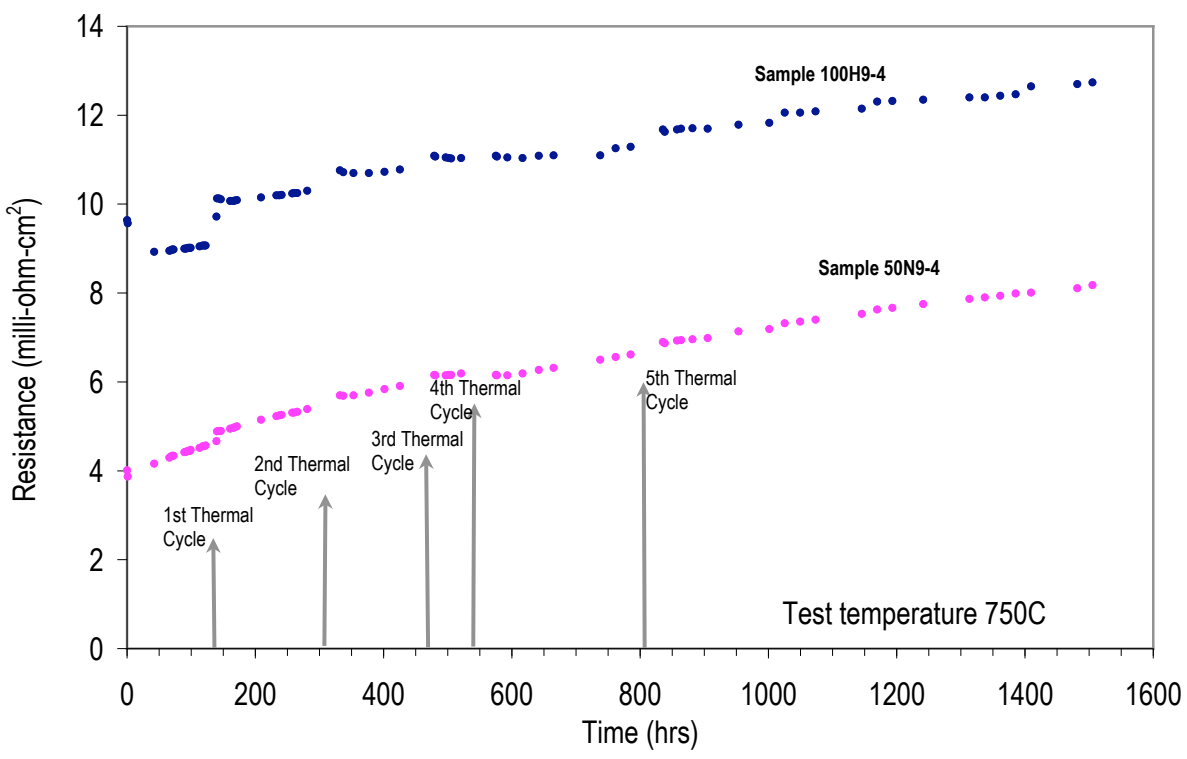

Figure 10. Resistance of Coupon Couples in Dry Air at $750^{\circ} \mathrm{C}$ 
In addition to the proposed evaluations, investigations related to oxide morphology and growth rates in wet air were also conducted.

\section{Scale Morphology}

Several treatment processes were evaluated. For simplicity, only a few of those exposed to dry and wet air at $750^{\circ} \mathrm{C}$ for 500 hours are presented Figure 12a through $12 \mathrm{f}$. The micrographs shown are for untreated metal and two surface treatments. In general, the untreated samples show poor scale adhesion both in dry and wet air exposures. Both treatments show well adhered scale in dry air and wet air exposures. The treatment process 100H9-4 shows some instability in the scale structure, while the process 50N9-4 shows much more stable scale microstructure. Treatment NT-0 for the fuel side produces a scale that is well-adhered after 72 hour exposure time.

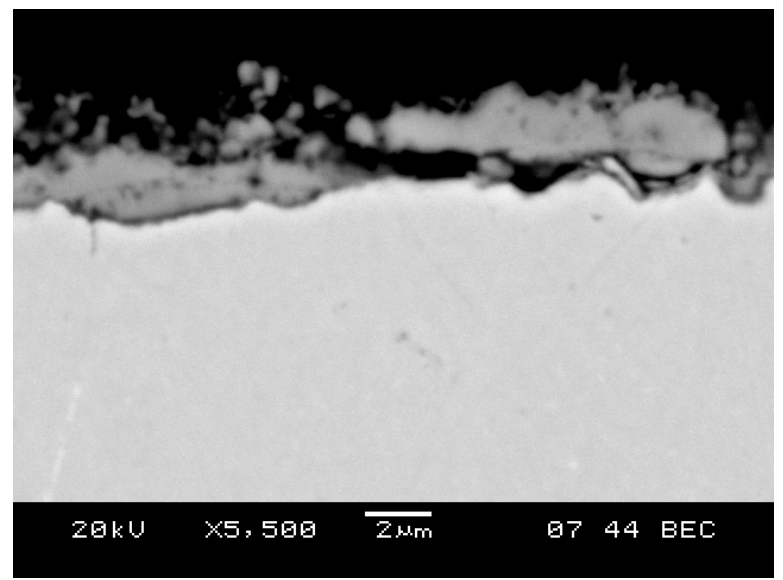

Untreated metal dry air $750^{\circ} \mathrm{C} 200$ hours

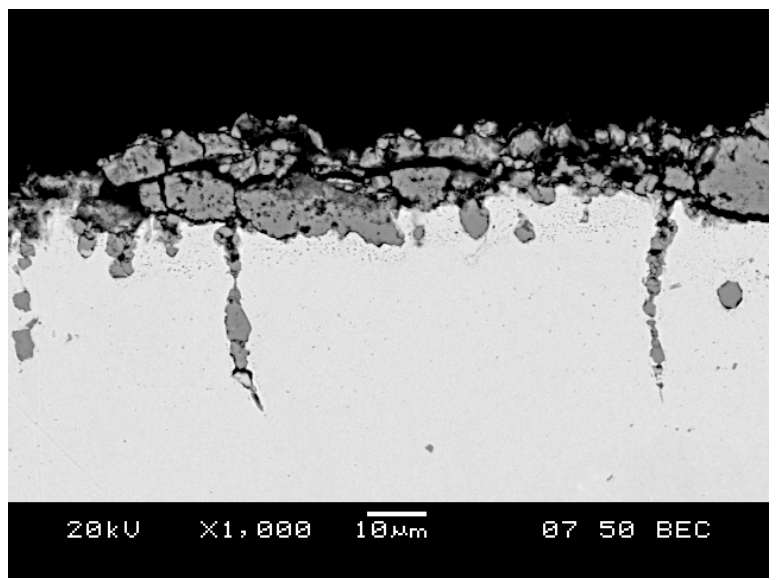

Untreated metal: wet air $750^{\circ} \mathrm{C} 500$ hours

Figure 11. Micrographs of Untreated Metal The scale is not well-adhered in dry air; scale loses integrity in wet air

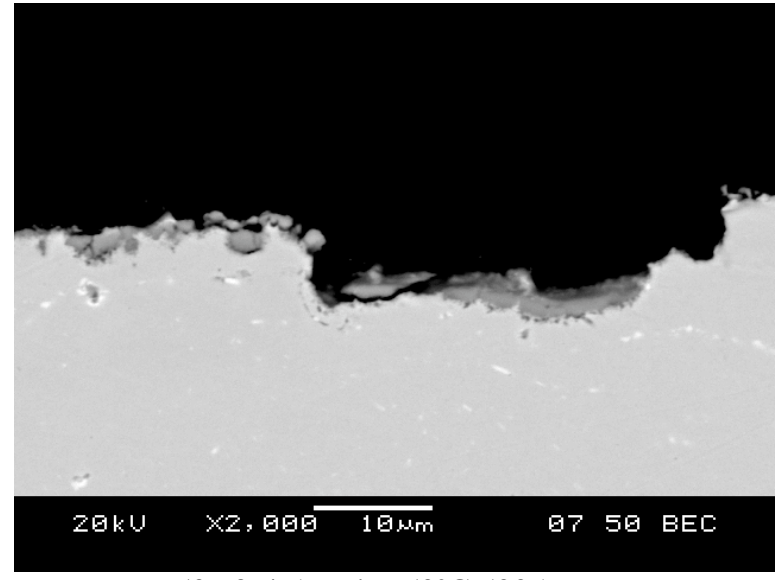

50N9-4 dry air $750^{\circ} \mathrm{C} 500$ hours

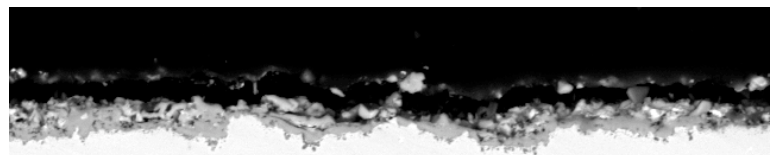

Figure 12. Micrographs of Treated Coupons (Process 50N9-4)

Scale is well-adhered in both dry and wet air 


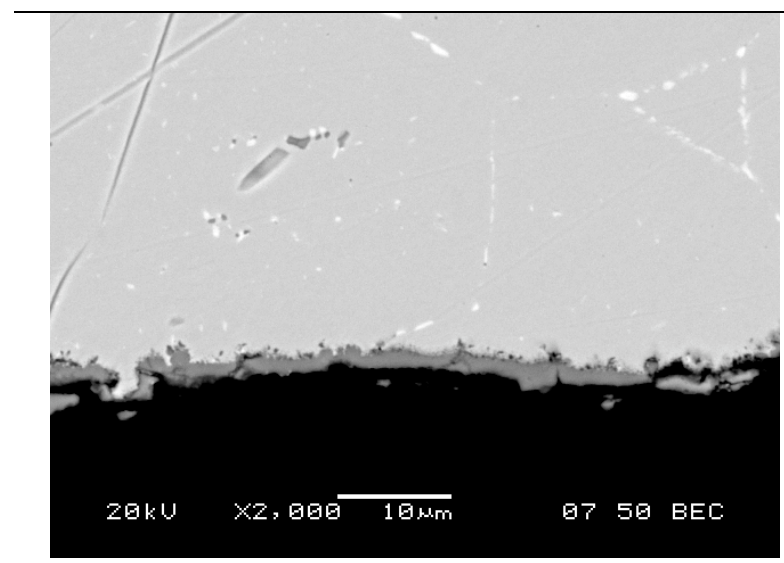

100H9-4 dry air 500 hours

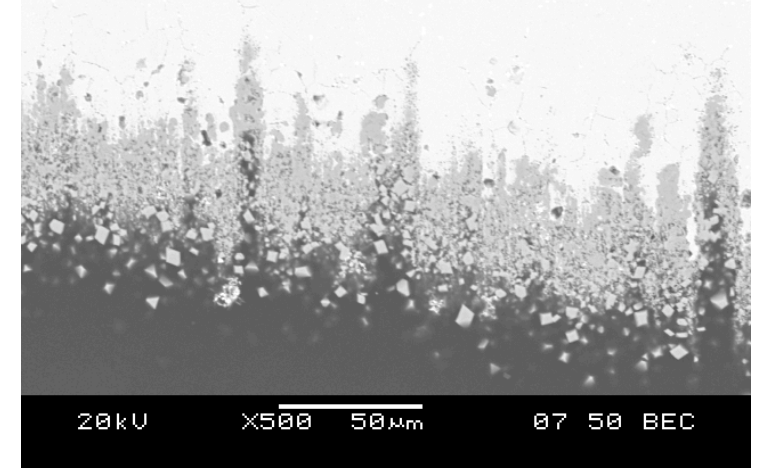

100H9-4 500 hours in wet air

Figure 13. Micrographs of Treated Coupons (Process 100H9-4) Well-adhered scale in dry air

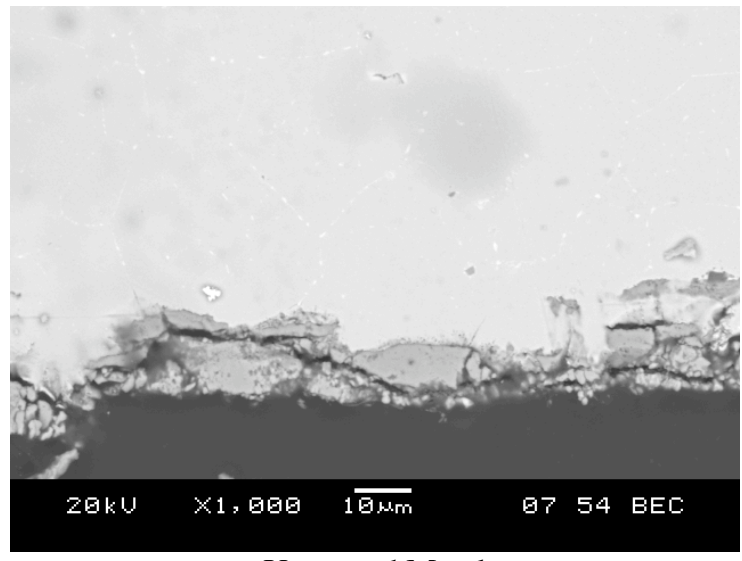

Untreated Metal

Dry air side $750^{\circ} \mathrm{C} 500$ hours Scale cracking seen

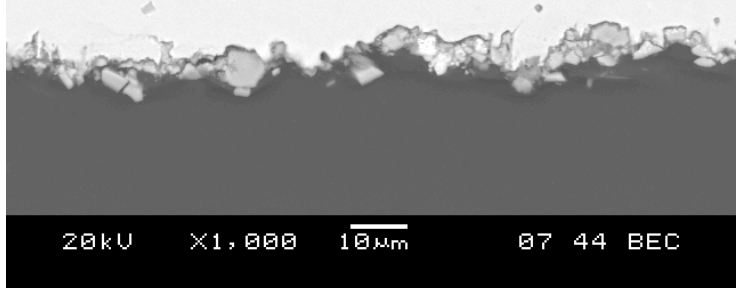

Process: 50N9-4

Dry air side 500 hours $750^{\circ} \mathrm{C}$ Good adhesion

Figure 14. Micrographs of Dry Air Side of Dual Atmosphere Test

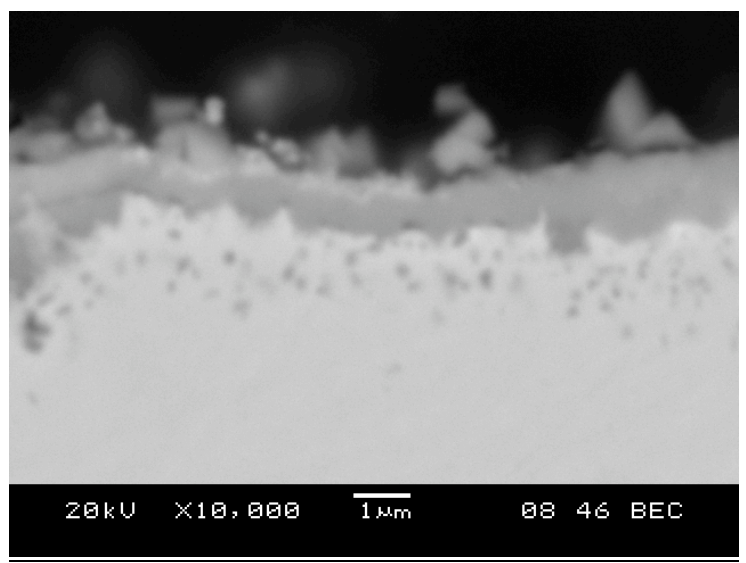

Figure 15. Micrograph for Process 50N9-4 Conductivity Tested Sample

Dry air $750^{\circ} \mathrm{C} 500$ hours

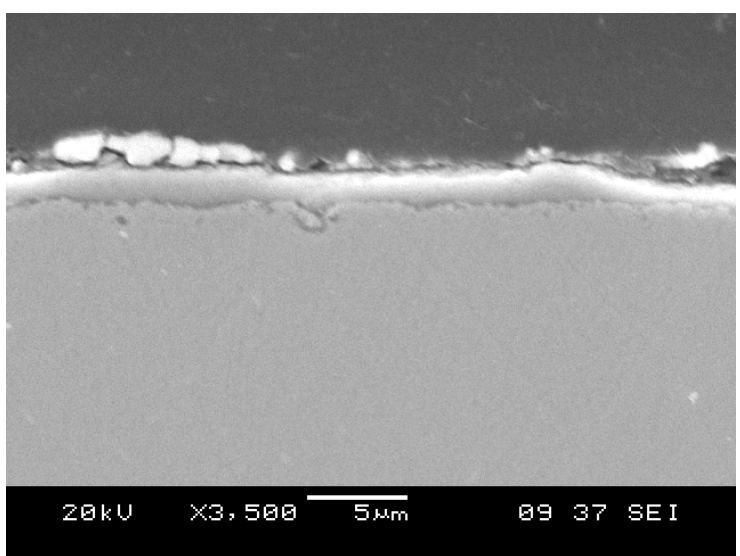

Figure 16. Micrograph for Process NT-0 in Wet Hydrogen 72 hours in at $750^{\circ} \mathrm{C}$ 


\section{Scale Composition}

The various scale compositions developed over the 500 hour exposure at $750^{\circ} \mathrm{C}$ were analyzed using $\mathrm{x}$-ray diffraction technique. The initial set of analyses in Phase I was conducted on the scale compositions on air-side of the coupon. Figure 18 shows the x-ray diffraction patterns of untreated samples that were exposed to dry or wet air (approx. 3\% humidification). The surface analyzed and the exposure conditions are noted in the Figure. As can be seen, the oxide scale composition that develops during the exposure is different depending upon the exposure conditions. The dry air exposure develops predominantly Fe based oxides, while the wet air exposure promotes the growth of $\mathrm{Cr}$ based oxides.

A similar evaluation was also performed for various exposure conditions for the treated metal coupons that were exposed to different single and dual atmospheres at $750^{\circ} \mathrm{C}$ for 500 hours. The exposure atmosphere ranged from dry or wet air on both sides to dry and wet air across the sample and dry air and wet hydrogen across the sample. The x-ray diffraction spectra of the scale composition are shown in Figure 19. The spectra of the air-side oxide scale for all exposure conditions, with the exception of air - hydrogen dual atmosphere, show identical peak positions. The spectra are indexed to the targeted chromium containing oxide scale that is not only electronically conductive, it is also lower in chromium activity than a chromia scale. This is expected to reduce the evaporation of chromium, which when it condenses on the cathode surface is known to reduce cathode activity.

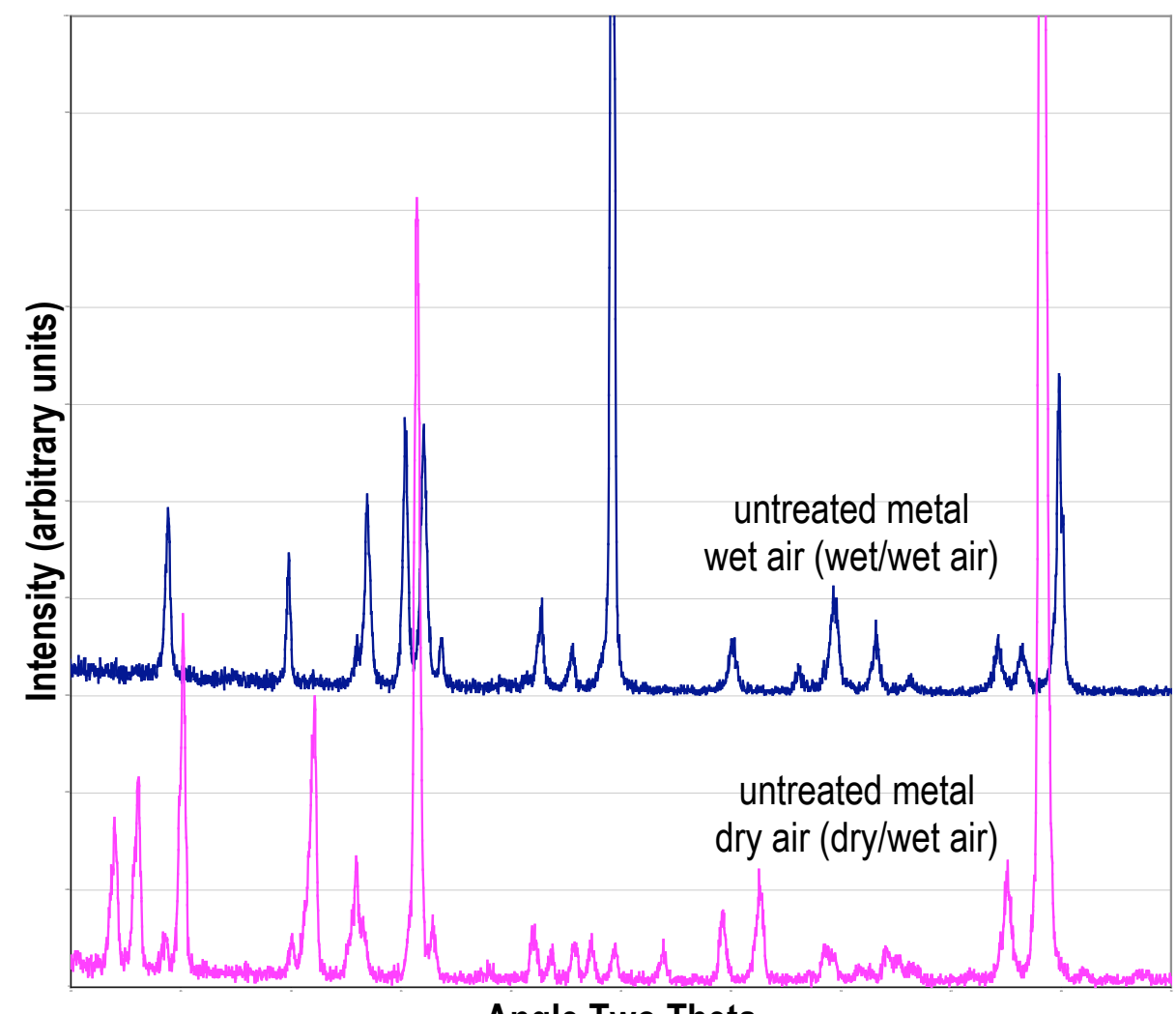

Angle Two Theta

Figure 17. X-Ray Diffraction Patterns of Untreated Coupons (500-hour exposure at $750^{\circ} \mathrm{C}$ ) 


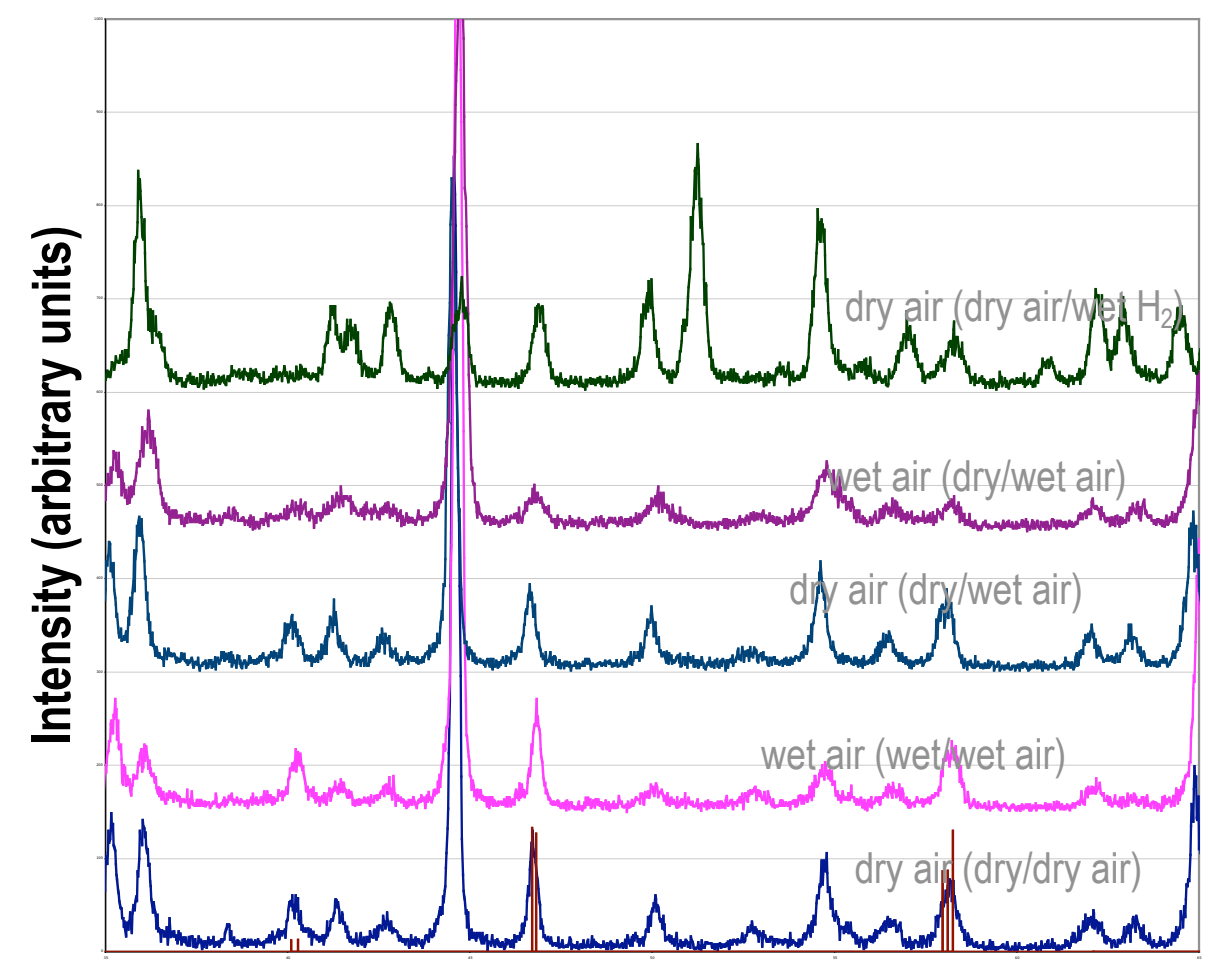

Angle Two Theta

Figure 18. X-Ray Diffraction Patterns of Treated Coupons

(500-hour exposure at $750^{\circ} \mathrm{C}$ )

All the key milestones proposed were successfully completed. Additional tasks that were included based on feedback from peer group have also been nearly completed. In fact, new test set up (iR-stack) to evaluate full size interconnects has been added in place of a stack test in order to measure the interconnect performance in dual atmosphere and realistic cross-flow conditions. The milestones and accomplishments are shown in Table 3. 
Table 3. Key Milestones Proposed in Phase I and Accomplishments

\begin{tabular}{|c|c|c|}
\hline Proposed Task & Description of Milestone & Accomplishment \\
\hline Alloy Selection & Low-cost commercial alloy & $\begin{array}{l}\text { Commercial ferritic stainless steel was } \\
\text { selected }\end{array}$ \\
\hline Surface treatment & $\begin{array}{l}\text { Target: Limit oxide scale } \\
\text { growth rate }\end{array}$ & Multiple treatment conditions were evaluated \\
\hline Weight gain in air & $\begin{array}{l}\text { Measure weight gain as a } \\
\text { function of time at } \\
\text { temperature }\end{array}$ & $\begin{array}{l}\text { Completed. Two surface treatment conditions } \\
\text { that significantly reduce the oxide scale } \\
\text { growth were identified. }\end{array}$ \\
\hline $\begin{array}{l}\text { Microstructural } \\
\text { characterization }\end{array}$ & $\begin{array}{l}\text { Need thin, dense, well- } \\
\text { bonded oxide scale }\end{array}$ & $\begin{array}{l}\text { Dense oxide layer of less than } 2 \text { microns after } \\
\text { exposure in dry and wet hydrogen. }\end{array}$ \\
\hline \multirow{2}{*}{$\begin{array}{l}\text { Conductive } \\
\text { coating }\end{array}$} & $\begin{array}{l}\text { Needed to lower in-plane } \\
\text { resistance }\end{array}$ & $\begin{array}{l}\text { Coating process defined (thermal spray } \\
\text { selected - Low cost process). }\end{array}$ \\
\hline & 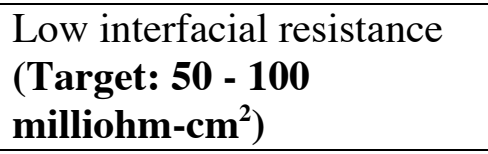 & 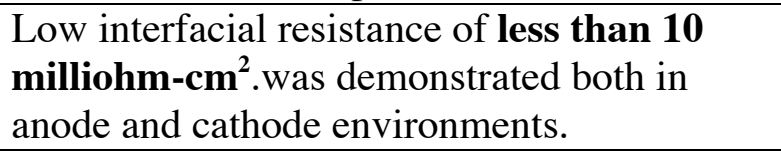 \\
\hline $\begin{array}{l}\text { Thermal Cycle } \\
\text { Effect }\end{array}$ & $\begin{array}{l}\text { Planned thermal cycles: } \\
\text { Three }\end{array}$ & 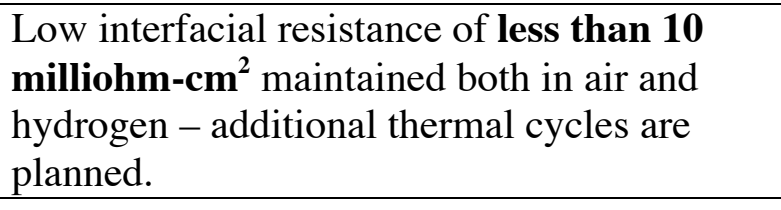 \\
\hline Add-on Tasks & Description & Accomplishment \\
\hline $\begin{array}{l}\text { Effect of exposure } \\
\text { to humidified air }\end{array}$ & $\begin{array}{l}\text { The scale composition and } \\
\text { adhesion may be different } \\
\text { in presence of moisture }\end{array}$ & $\begin{array}{c}500 \text { hours at } 750^{\circ} \mathrm{C} \text { exposure completed } \\
\text { Pre-treatment condition with well-adhered } \\
\text { scale identified. }\end{array}$ \\
\hline $\begin{array}{l}\text { Effect of exposure } \\
\text { to dual } \\
\text { atmosphere }\end{array}$ & $\begin{array}{l}\text { The scale property on air } \\
\text { side may be affected by the } \\
\text { presence of fuel on the } \\
\text { opposite side }\end{array}$ & $\begin{array}{c}500 \text { hours at } 750^{\circ} \mathrm{C} \text { exposure completed } \\
\text { Same pre-treatment process provides stable } \\
\text { scale on the air side. }\end{array}$ \\
\hline
\end{tabular}

The treatment that showed low resistance in dry air also showed low weight gain (slow scale growth rate), well-adhered morphology in both dry and wet air exposure, and a stable scale composition. The x-ray diffraction analyses of the scale after long term exposure in air at $750^{\circ} \mathrm{C}$ showed that certain pre-treatment process not only provided a dense scale layer, it also allowed in-situ conversion of the scale composition to contain chromium oxide $\left(\mathrm{Cr}_{2} \underline{\mathrm{O}}_{3}\right)$ and a low chromium activity stable and conductive scale. This is a significant finding and it correlates with both low rate of weight gain and scale stability. Additionally, it provides a pathway for additional improvements to the stability. If the pre-treatment process can be further optimized to create much higher content of the low chromium activity conductive scale phase, the stability is expected to improve. 


\section{Summary of Findings}

The untreated metal surface exhibits poorly adhered scale in dry air, wet air as well as the dry air side of dual atmosphere exposure.

P Process 50N9-4 provides scale with good adhesion in dry air, wet air, as well as the dry air side of dual atmosphere exposure.

0 Process 100H9-4 provides scale with good adhesion in both dry and wet air. However, in wet air the outer surface of the scale does not appear well defined.

$\square$ An SEM of a sample with 50N9-4 treatment after the conductivity testing for several hundred hours is also shown. The scale is less than two micron thick and well adhered to the base metal.

- Several other treatment processes (not shown) provide only a slight improvement in scale integrity over the untreated metal.

0 Various treatment processes for the fuel side were evaluated and down selected.

The process that gives stable scale was also found to show the lowest weight gain when the coupons are exposed to dry or wet air.

4 The treatment process results in a low chromium activity conductive phase that is shown to be stable in SOFC atmosphere. 


\section{CONCLUSION}

The Phase I project resulted in significant advances in the area of solid oxide fuel cell (SOFC) metal interconnect development. Methods to pre-treat and coat a commercial stainless steel were developed. The treated metal coupons showed exceptional oxide scale stability in SOFC relevant atmospheres and temperatures. The measured resistance values of 10 millohm$\mathrm{cm}^{2}$ in air and one milliohm- $\mathrm{cm}^{2}$ in humidified hydrogen at $750^{\circ} \mathrm{C}$ were substantially lower than the target resistance. The resistance values were stable over a limited number of thermal cycles carried out during the project. Additional development work is needed to improve the stable phase content in the scale to enhance the stability further and to evaluate the alloy when it is exposed to air and fuel conditions on opposite sides. Successful completion of these tasks will play a major role in enabling the SOFC system as a commercial reality. 


\section{REFERENCES}

1. Z.G. Yang, D.M. Paxton, K.S. Weil, J.W. Stevenson, and P. Singh "Materials Properties Database for Selection of High-Temperature Alloys and Concepts of Alloy Design for SOFC Applications," Pacific Northwest National Laboratory, Richland, Washington 99352, May 2002.

2. K. Hilpert W.J. Quaddakkers and L. Singheiser, Chapter 74 - Interconnects, Handbook of Fuel Cells, Volume 4: Fuel Cell Technology and Applications, John Wiley \& Sons, Ltd. 2003.

3. E. Batawi et al., SOFC VI, Electrochem. Soc., Eds. S. C. Singhal and M. Dokiya, 99-19, p. 731, Honolulu, HI, (1999).

4. N. Patibandala et al., J. Electrochem. Soc., vol. 138 (7), p. 2176 (1991).

5. P.Y. Hou, J. Stringer, Mat. Sci. and Engr., p. 132, vol. 58 (1995).

6. Nonstoichiometry, diffusion, and electrical conductivity in binary metal oxides, P. Kofstad, Wiley Interscience Publication, 1972, p. 204.

7 D.M. England and A.V. Virkar, J. Electrochem. Soc., vol. 148 (4), p. A330 (2001). 